\title{
Students' Academic Self-Esteem and Academic Achievement Relationships in Public Secondary Schools in Nakuru County, Kenya
}

\author{
Addero Wilson Ogot ${ }^{1} \quad$ Chepchieng Micah $^{2} \quad$ Kariuki Mary ${ }^{2}$ \\ 1. Doctorate Student in Educational Psychology of Egerton University \\ 2. Department of Psychology, Counseling and Educational Foundations, Egerton University
}

\begin{abstract}
Academic achievement is important in the determination of a students' future prospects. Educationists and other stakeholders have consistently used students' academic achievement results as basis of advancement and employment opportunities. The learners' academic self-esteem correspondingly shape the learning environment of students. The purpose of this study was to examine students' academic self-esteem and academic achievement relationships in public secondary schools in Nakuru County, Kenya. Correlational research design and both quantitative and qualitative research approaches were used in the study. The population of the study comprised 23,309 from 29 public secondary schools. The sample size for the study was 407 respondents, comprising of 378 form three students and 29 class teachers. The study used closed-ended questionnaires to collect data on selfesteem from students and interview schedule to collect data from class teachers. Self-esteem scale was adopted and adjusted using Rosenberg Self-esteem Inventory. Data for academic achievement was obtained from school examinations results record. Cronbach's Alpha test of internal constituency for self-esteem questionnaire had reliability coefficients of 0.873 which was considered acceptable. The study found out that there was a significant relationship between students' academic self-esteem and academic achievement in public secondary schools in Nakuru County, Kenya. The study concluded that students' academic self-esteem affects their academic achievement. In respect to this, the study recommended the Kenya Institute of Curriculum Development (KICD) to develop a curriculum or teaching methods that seeks to improve students' academic self-esteem for better academic achievement.
\end{abstract}

Keywords: Academic Self-Esteem, Academic Achievement

DOI: $10.7176 / \mathrm{JEP} / 11-24-18$

Publication date:August $31^{\text {st }} 2020$

\section{Introduction}

Background to the Study

Academic achievement is globally paralleled as an indicator of intellectual ability of a learner in a given educational system. A student is expected to work towards obtaining good academic achievement attained over a certain period of time (Cuesta, 2018). In the context of secondary schools, academic achievement is measured through students' mean scores in the administered examinations (Murunga \& Obuba, 2017; Ntawiha, 2016; Suleman \& Gul, 2015). Poor academic achievement is likely to result in the students' lack of opportunities to progress in higher learning, limited opportunities in the technical training institutions and missed employment opportunities in careers of choice. A country is also likely to lack skilled manpower necessary to achieve its national agenda and attract international investors (Gupta \& Mili, 2016).

Poor academic achievement is likely to result in the students' lack of opportunities to progress in higher learning, limited opportunities in the technical training institutions and missed employment opportunities in careers of choice(Cuesta, 2018). A study in India by Gupta and Mili (2016) noted that as students performed below average it hindered their academic progression to higher levels of learning. When the students in a country fail to perform well in their academics the future of the country is considered ineffectual in terms of skilled man power. In Turkey, Bahar (2016) observed a massive failure of students in their academic achievement that posed a threat to the future labor market competencies. This also called for setting up of bodies tasked to inspect the causes of 
underperformance in Turkey. In Indonesia for example, a special inquiry commission was also formulated to investigate the cause of poor academic achievement of high school students (Riswanto \& Aryani, 2017).

Self-esteem also plays a critical role in determining how students interacts with individuals who help the student achieve the set academic achievement (Sahin, Barut, Ersanli, and Kumcagiz, 2014). Self-esteem is defined as a personality trait that describes person's sense of self-worth Muhammad, Muhammad, and Mahmood, (2015). On the educational context, Maruyana, Rubin, and Kingsbury (2016) conceptualizes self-esteem to be the belief that the student can have better academic achievement. Student academic self-esteem can be indicated by the level of assertiveness in class tasks, ability to communicate in class, attitudes towards self in regard to learning capabilities and ability to take leadership role in group discussions among other aspects (Kithela, 2016).

Self-esteem plays also a great role in determining the levels of associations between individuals within a school situation which may involve academic pursuing interactions by students. In a study In the USA, Orth and Robins (2014) noted that when students were faced with self-esteem related challenges they were hindered from seeking assistance from their teachers, parents and even fellow students. On the same context, Masselink, Roekel, and Oldehinkel (2018) establish poor interactions among students and their teachers were occasioned by cases which were likely to have a negative effect on the teacher-student classroom based relationship.

In addition, a study by Sharma and Agarwala (2015) noted challenges of students as a result of low selfesteem included reduced assertiveness, poor communication skills and negative attitudes towards seeking academic assistance. A study by McGaha-Garnett (2017) revealed that there was a significant relationship between the academic self-esteem and academic achievement of the students. On Nigerian context, Maruyana et al.(2016) found out that there was significant difference between academic achievement of students with high self-esteem and students with low self-esteem. Okolo, Ofielu, Nebo, and Nebo (2017) in Nigeria found out that there was a significant relationship between student academic self-esteem and the academic achievement of students.

\section{Statement of the Problem}

According to the Kenya Certificate of Secondary Education (KCSE) results for the years 2013-2017, the academic achievement of secondary in Kenya has not been satisfactory despite the importance attached to success in academic work. Among the counties in Kenya, Nakuru county has consistently recorded a mean score below the national mean score as well as below the average mean score of 6.00 (C-plain) in the Kenya Certificate of Secondary Education. In addition, Nakuru County performs poorer than other similarly cosmopolitan counties in Kenya such as Kilifi, Kajiado County and Trans Nzoia County among others. Students are constantly faced with many academic challenges as they progress in their education. This study hypothesizes that the level of self-esteem of a student may affect how the student works towards achieving the set academic goals. Despite academic achievement of students in secondary schools in Kenya having drawn attention of researchers and education stakeholders, there is paucity of comprehensive and conclusive study carried out to establish the relationship between student academic self-esteem and academic achievement, which are the variables of the current study.

\section{Objective of the Study}

To determine the relationship between students' academic self-esteem and academic achievement in public secondary schools in Nakuru County, Kenya.

\section{Research Hypothesis}

Ho1: There is no statistically significant relationship between students' academic self-esteem and academic achievement in public secondary schools in Nakuru County, Kenya.

\section{Literature Review}

\section{Students' Academic Self-Esteem and Academic Achievement}

Empirical studies in Kenya and outside Kenya have shown relationship between self-esteem and academic achievement of student in diverse ways. From Pakistan, Muhammad et al. (2015)carried out a study to establish the relationship between self-esteem and academic achievement of secondary school students. The study found out that there was a significant relationship $(\mathrm{r}=0.879, \mathrm{p}<.01)$ between self-esteem and academic achievement. There was a significant difference on self-esteem and academic achievement scores between male and female 
students. Female students had high scores on academic achievement as compared to male students while male students had high scores on self-esteem as compared to female students.

In Azerbaijan Democratic Republic, Muhammud (2015) carried out a study to find out the Relationship between Self-Esteem and Academic Achievement among Pre-University Students. The study aimed at identifying whether there are differences between the academic achievement of boys and girls based on their levels of selfesteem. The study established that there was a significant $(\mathrm{p}<0.01)$ positive relationship between self-esteem and academic achievement of pre-university students. Also the study found out that there existed significant differences between academic achievement of girls and boys. However, the study found out that there was no significant differences between the self-esteem of boys and that of girls. The study concluded that self-esteem is a good predictor of academic achievement.

Phil, Sattar, Khan, and Phil (2014) carried out a study to investigate the influence of academic self-esteem on the academic achievement of students in Pakistan. The study recommended that students develop positive perception towards academic activities in the school and therefore leading to better academic achievement of the students. This was also in line with a study by Srivastava and Joshi (2014) who found a positive relationship between student academic self-esteem and academic achievement of the students.

A study by McGaha-Garnett (2017) sought to establish among other objectives the influence of academic self-esteem on the academic achievement of students from Oklahoma State in the United States of America. From the collected data, it was established that student with high academic self-esteem achieved high mean grades in their academics and the vice versa. It was revealed that there was a significant relationship between the academic self-esteem and academic achievement of the students. In respect to this, it was further revealed that self-esteem of students significantly predicted the academic achievement of the students.

A study carried out in the United Kingdom by Vass et al., (2015) sought to investigate the influence of self-esteem on the academic achievement of students among other objectives. The study revealed that there was a negative association between low self-esteem and academic achievement of students. It was in this regard noted that a low self-esteem led to hopelessness in achieving the targeted academic results. The study recommended the motivation of students towards better academic achievement through changing their attitudes toward studies.

Alyami, Melyani, Johani, and Ullah (2017) carried out a study to investigate the influence of academic self-esteem on the academic achievement of students. The study established that there was a moderate correction $(\mathrm{r}=0.488)$ between student academic self-esteem and academic achievement. Students with high academic selfesteem were seen to perform better in academics than those with low academic self-esteem. The researcher recommended that students to be boosted on their academic self-esteem through motivational talks as well as rewarding good academic achievement.

The relationship between academic self-esteem and the academic achievement was examined by Durmaz (2016) in a study on secondary school student mothers in Turkey. The study revealed that there was a positive and significant correction between student mothers' academic self-esteem and their level of academic achievement. It was in this regard noted that the student mothers who were positive perception about childbearing and motherhood outperformed those who has a negative perception on motherhood as students. The study by Durmaz (2016) was on student mothers while the current study will be done on general students in secondary school regardless on their parenting status. This therefore presented contextual research gap for the current study.

Serati (2015) carried out a study to examine the relationship between academic self-esteem and academic achievement of secondary school girls in Iran. The study revealed that there was a significant relationship between the level of academic self-esteem and the level of academic achievement of the students. It was in this respect revealed that those students that were highly motivated towards higher academic grades and entire activities of school learning had a better academic achievement as compared to those who were less motivated towards the same. The study recommended that students to be more motivated towards improving their academic self-esteem. In Pakistan, Farhan (2015) carried out a study to examine the effect of academic self-esteem and student academic achievement. The study revealed that there was no significant correlation between self-esteem and the academic performance of students.

On Nigerian context, Akaase and Okpechi (2018) sought to investigate the relationship between academic self-esteem and academic achievement of the students in mathematics and English Language. The findings showed that there was a significant difference in the academic success of students with positive self-esteem than those with 
negative self-esteem. It was concluded that self-esteem significantly influenced students' academic success. Based on findings of the study, it was recommended that students should boost their self-esteem as it is an important factor that strengthens the prediction of academic success in Mathematics and English Language. It was further noted that there should be school counseling intervention in improving self-esteem among students. Students should be trained on how to improve greatly in their self-esteem and academic efficacy.

Maruyana et al.(2016) did a study on the influence of self-esteem on academic achievement among secondary school students in Nigeria. The study set out to test the null hypothesis that there is no significant difference between academic achievement of students with high self-esteem and students with low self-esteem. In testing the null hypothesis of the study, it was found out that there was significant difference between academic achievement of students with high self-esteem and students with low self-esteem. The study rejected the null hypothesis and concluded that students with high self-esteem perform better in school work than students with low self-esteem.

Okolo, Ofielu, Nebo, and Nebo (2017) carried out a study to examine the factors that affect the academic achievement of secondary school students in Nigeria. Among the factors that the study established to influence the academic achievement of students included student academic self-esteem. In respect to this, the study found out that there was a significant relationship between student academic self-esteem and the academic achievement of students. It was noted that students who were academically motivated performed better in their examinations compared to those who had low academic self-esteem. The study recommended teachers and parents to motivate the students in order to improve their academic achievement.

On Kenyan context, Kithela (2016) carried out a study to investigate how school type was related to selfesteem, academic achievement and career aspirations of secondary school students. Kithela (2016) found out that there was significant relationship between school type and self-esteem of students, academic achievement and career aspirations. In this regard, the study found out that most of the students from national and extra-county schools had high self-esteem, and aspired for high professional careers compared to majority of sub-county students' who exhibited low self-esteem and aspired for low-level careers.

Focusing on student intrinsic factors, Mutua (2014) carried out a study on academic motivation and selfregulated learning as predictors of academic achievement of students in public secondary schools in Nairobi County, Kenya. The main aim was to determine a prediction model of secondary school students' academic achievement given academic motivation and self-regulated learning. Among the metric of self-regulated learning, the study established that there was significant relationship between self-esteem and academic achievement of the students.

\section{Theoretical Framework}

This study used two theories, which are; Maslow's Hierarchy of Needs Theory and Goal Theory. Maslow's Hierarchy of Needs Theory guided the study in regard to academic self-esteem while Goal Theory was used to guide the study in respect to academic achievement.

\section{Maslow's Need Hierarchy Theory}

Maslow's Need Hierarchy theory was developed by Abraham Maslow in 1954. The theory states that human beings are motivated by intrinsic needs. According to Maslow (1954), the needs follow a specific hierarchy. The first hierarchy of needs is physiological needs and includes the most basic needs such as warmth, water, rest, food. The second hierarchy is safety needs which includes personal security, financial security, health, wellbeing and protection. The third hierarchy of needs is love and need to belong (affiliate). This hierarchy includes needs such as intimate relationships and friends. The fourth hierarchy of needs is esteem and comprises of needs such as respect, feeling of accomplishment, prestige and confidence. The fifth and last hierarchy of needs is selfactualization needs (Hasebur Rahman \& M. Nurullah, 2015). This hierarchy comprises of fulfilling one's full potential as well as creatives needs.

Maslow's Need Hierarchy theory further states that lower needs must be satisfied before one can progresses to the next level of needs (Einstein, Addams, \& Roosevelt, 2016). Maslow's theory classifies needs into two subsidiary sets. The first set is conceptualized on the desire for strength, for achievement, for adequacy, for confidence in the face of the world, and for independence and freedom. The second set involves the desire for 
reputation or prestige, recognition, attention, importance or appreciation. The second set is mainly concerned about respect or esteem from other people. Therefore the desire to achieve more for self-actualization purposes is central to Maslow's theory of hierarchy of needs. In school set up, once a student achieves certain level of recognition or attains a specific level of academic achievement, the student will thereafter desire more academic achievement. To achieve higher targets, the student will needs more psychological "appetite" which in this study is conceptualized to be self-esteem. Self-esteem acts as a psychological drive that seeks higher levels of selfactualization (Bean, Bush, McKenry, \& Wilson, 2013).

However, the desire to achieve more according to Maslow's Theory is within the potential of one's self. It refers to the need to do what one is fitted for. It refers to the desire for self-fulfillment, that is, the tendency for one to become actualized in what is potentially capable of. This is the desire to become more and more what one is or to become everything that one is capable of becoming. The process in which students exploit their potential through the desire to become more and more of their self is sufficiently explained by Maslow's Theory. This study will apply this theory in the context of students seeking more academic achievement and therefore believing in themselves that they can achieve higher levels of academic achievement. This believe was conceptualized as the self-esteem that a student needs to achieve higher academic achievement than previous results. Therefore Maslow's theory was used to explain how self-esteem among the students affects their level of academic achievement. This theory has been used by other researchers in related studies as the current study. These researchers include (Kithela, 2016) in a study on the relationship among school type and secondary school students' self-esteem, academic achievement and career aspirations in Nairobi County. Maruyana et al.(2016) used the same theory on the influence of self-esteem on academic achievement among secondary school students.

\section{Goal Theory}

Goal theory is the theory used in educational psychology to describe how students' self-esteem leads to higher academic grades. Goals of learning are thought to be a key factor influencing the level of a student's intrinsic motivation. The Goal Theory proposes that there are two types of motivation for achievement in school. These types are; Performance goal orientation and task goal orientation. Students with performance goal orientation are interested in getting good grades or having a higher academic achievement as compared to fellow students (Anderman \& Midgley, 1997). On the other hand, students with a task goal orientation are motivated in increasing their knowledge on the subjects offered in school and enjoy in learning new concept. Task goal orientation enables students to engage in challenging tasks and are motivated in applying cognitive strategies, to understand a concept if seek assistance (Elliot, 2006).Both performance goal orientations and task goal orientation are also associated with academic achievement of students (Kaplan \& Maehr, 2007).

Urdan and Midgley (2003) further improved the goal theory by describing four types of goals based on social interaction of students. These goals are social approval, social compliance, social solidarity, and social concern. In social approval, a student engages in academic activities in order to be approved or recommended for good work done. In social compliance, student does what is right and recommended to do in terms of academic achievement. Urdan and Midgley (2003) described social solidarity as a situation whereby students work together for a common good which is witnessed through group discussion and class debates among other activities that promote academic achievement. Students in a school setup always want to achieve the objective of them being in school and also the expectations of their parents as explained in social concern goal.

Browne and Cudeck (1993) investigated the goal theory and found that students showed characteristics of four different goal orientations: work avoidance, social affiliation, social responsibility, and social concern. Work avoidance related to students attempting to avoid class work or copying from other students. This also covers off-task behaviors witnessed in lazy students. Social affiliation orientation on the other hand is whereby students work with their peers which creates a sense of belonging and this helps them work more effectively and promoted positive feelings toward learning. Browne and Cudeck (1993) asserted that students with a social responsibility goal orientation were motivated by a desire to fulfill their role expectations. These included parent, teacher, and peer expectations such as participating in extracurricular activities, helping fellow peers and behaving responsibly if in student council position. Students feel proud of themselves and satisfied when they meet these expectations. Lastly, students with a social concern orientation work hard to succeed so that they could then help others. 
This theory applies to this student in explaining the academic achievement of students in secondary schools. The students have different motivations towards their academic achievement and these reasons are outlined in the goal theory. The goal theory has been used by (Luo et al., 2014) to examine the self-construal and students' math self-concept, anxiety and achievement. This theory has also been previously used by related studies in Kenyan context, for example by (Mutua, 2014) in studying academic motivation and self-regulated learning as predictors of academic achievement of students in public secondary schools in Nairobi County, Kenya. Therefore the theory will effectively guide the study in regard to student achievement.

\section{Conceptual Framework}

In examining the relationship between student academic self-esteem and academic achievement, the study hypothesizes the association between variables as shown in Figure 1. Other factors that this study conceptualizes to affect academic achievement was student IQ and the availability of learning resources.

\section{Independent Variable Intervening Variables $\quad$ Dependent Variable}

\begin{tabular}{|c|c|c|}
\hline $\begin{array}{l}\text { Student Self-esteem } \\
\text { - Assertiveness } \\
\text { - } \quad \text { Communication } \\
\text { - Attitudes }\end{array}$ & $\begin{array}{l}\text { - Student IQ } \\
\text { - Learning } \\
\text { resources }\end{array}$ & $\begin{array}{l}\quad \begin{array}{c}\text { Academic } \\
\text { achievement }\end{array} \\
\text { - Student mean score } \\
\text { in End of Term } \\
\text { Exams }\end{array}$ \\
\hline
\end{tabular}

Figure 1: Students' Academic Self-Esteem and Academic Achievement of Students

\section{Research Methodology \\ Research Design}

This study used correlational research design to integrate different components of the study to meet the study objectives.

\section{Target Population}

The study targeted all form three students from 294 public secondary schools in Nakuru County. All the target population was accessible and therefore the accessible population was equal to the target population. There were approximately 23,309 (11,938 boys and 11,371 girls) form three students, from the 294 public secondary schools in Nakuru County (Nakuru County Director of Education, 2018). In addition to the students, class teachers were also incorporated in the study.

\section{Sample Size and Sampling Procedures}

Using $10 \%$ of the population criteria, 29 public secondary schools out of a total of 294 schools were sampled for this study. On the other hand, the sample size of 378 form three students was determined using Krejcie and Morgan (1970) formula. Using stratified random sampling procedure, the study selected the 29 public secondary schools in Nakuru County and the 378 form three students. The type of the school was used as the stratification criteria. From each stratum, the number of students to be selected was determined by the stratum size and after which the individual students were selected randomly. One class teacher from each of the 29 selected public secondary school in Nakuru County was selected to participate in the study using purposive sampling. The total sample size for this study was 407 respondents.

\section{Instrumentation}

The study used both primary data and secondary data. For primary data, the study used closed-ended questionnaires to gather data on self-esteem from students and guided interview schedule to collect data from class teachers. Selfesteem scale was adopted and adjusted using Rosenberg Self-esteem Inventory. For secondary data, the study obtained the data on student academic achievement from examination records. 


\section{Validity of the Research Instrument}

To ensure content validity of the research instruments, the researcher constructed questionnaire and interview schedule in line to the research objectives of the study. The two supervisors of this study and experts from the Faculty of Education and Community Studies Egerton University cross-checked whether the research instruments measure what the study intended to measure.

\section{Reliability of the Research Instrument}

To test the reliability of research questionnaires, the researcher pilot-tested the instruments. The data obtained from the pilot study was used to test the internal consistency of the research instrument using Cronbach's Alpha coefficient. The Cronbach's Alpha coefficient of 0.873 for Student academic self-esteem construct was achieved implying that the instruments yielded consistent data.

\section{Data Analysis}

The filled questionnaires were coded and entered into the Statistical Package for Social Sciences (SPSS) version 24 for quantitative data analysis. Both descriptive and inferential statistics were used in analyzing the data. For descriptive statistics, frequencies, mean and standard deviation were used to describe basic characteristics of the data. For inferential statistics, Pearson correlation analysis was performed to test the research hypothesis.

\section{Results and Discussion}

\section{Student Academic Self-Esteem}

Student academic self-esteem was measured in terms of student assertiveness in class tasks, ability to communicate in class, attitudes towards self in regard to learning capabilities and ability to take leadership role in group discussions among others. Table 1 shows the descriptive statistics for the statements rating the level of students' self-esteem.

Table 1: Student Academic Self Esteem

\begin{tabular}{|c|c|c|c|c|c|c|c|}
\hline \multirow[t]{2}{*}{ Description } & \multicolumn{5}{|c|}{ Frequency and Percentages } & \multicolumn{2}{|c|}{ Total } \\
\hline & $\mathbf{N}$ & $\mathbf{R}$ & $\mathbf{S}$ & $\mathbf{U}$ & $\mathbf{A}$ & Mean & Std. Dev \\
\hline Learning activities in the school is fun & $\begin{array}{c}37 \\
(11.1 \%)\end{array}$ & $\begin{array}{c}255 \\
(76.8 \%)\end{array}$ & $\begin{array}{c}11 \\
(3.3 \%)\end{array}$ & $\begin{array}{c}17 \\
(5.1 \%)\end{array}$ & $\begin{array}{c}12 \\
(3.6 \%)\end{array}$ & 1.13 & 0.812 \\
\hline I have strong academic capabilities & $\begin{array}{c}10 \\
(3.0 \%)\end{array}$ & $\begin{array}{l}11 \\
(3.3 \%)\end{array}$ & $\begin{array}{c}13 \\
(3.9 \%)\end{array}$ & $\begin{array}{c}222 \\
(66.9 \%)\end{array}$ & $\begin{array}{c}76 \\
(22.9 \%)\end{array}$ & 3.03 & 0.820 \\
\hline $\begin{array}{l}\text { I do academic preparation for examinations in } \\
\text { advance }\end{array}$ & $\begin{array}{c}49 \\
(14.8 \%)\end{array}$ & $\begin{array}{c}47 \\
(14.2 \%)\end{array}$ & $\begin{array}{c}48 \\
(14.5 \%)\end{array}$ & $\begin{array}{c}157 \\
(47.3 \%)\end{array}$ & $\begin{array}{c}31 \\
(9.3 \%)\end{array}$ & 2.22 & 1.238 \\
\hline I feel good when I am in a class learning & $\begin{array}{c}31 \\
(9.3 \%)\end{array}$ & $\begin{array}{c}236 \\
(71.1 \%)\end{array}$ & $\begin{array}{c}23 \\
(6.9 \%)\end{array}$ & $\begin{array}{c}36 \\
(10.8 \%)\end{array}$ & $\begin{array}{c}6 \\
(1.8 \%)\end{array}$ & 1.25 & 0.837 \\
\hline $\begin{array}{l}\text { I feel good about myself when I attain good } \\
\text { academic grades }\end{array}$ & $\begin{array}{c}9 \\
(2.7 \%)\end{array}$ & $\begin{array}{c}14 \\
(4.2 \%)\end{array}$ & $\begin{array}{c}10 \\
(3.0 \%)\end{array}$ & $\begin{array}{c}127 \\
(38.3 \%)\end{array}$ & $\begin{array}{c}172 \\
(51.8 \%)\end{array}$ & 3.32 & 0.927 \\
\hline $\begin{array}{l}\text { I enjoy spending many hours on academic } \\
\text { homework. }\end{array}$ & $\begin{array}{c}35 \\
(10.5 \%)\end{array}$ & $\begin{array}{c}210 \\
(63.3 \%)\end{array}$ & $\begin{array}{c}29 \\
(8.7 \%)\end{array}$ & $\begin{array}{c}41 \\
(12.3 \%)\end{array}$ & $\begin{array}{c}17 \\
(5.1 \%)\end{array}$ & 1.38 & 1.002 \\
\hline $\begin{array}{l}\text { I try hard to solve an academic problem until I } \\
\text { make it }\end{array}$ & $\begin{array}{c}18 \\
(5.4 \%)\end{array}$ & $\begin{array}{c}27 \\
(8.1 \%)\end{array}$ & $\begin{array}{c}31 \\
(9.3 \%)\end{array}$ & $\begin{array}{c}205 \\
(61.7 \%)\end{array}$ & $\begin{array}{c}51 \\
(15.4 \%)\end{array}$ & 2.73 & 0.996 \\
\hline $\begin{array}{l}\text { I would rather spend most of my time reading } \\
\text { as opposed to other activities }\end{array}$ & $\begin{array}{c}70 \\
(21.1 \%)\end{array}$ & $\begin{array}{c}189 \\
(56.9 \%)\end{array}$ & $\begin{array}{c}48 \\
(14.5 \%)\end{array}$ & $\begin{array}{c}13 \\
(3.9 \%)\end{array}$ & $\begin{array}{c}12 \\
(3.6 \%)\end{array}$ & 1.12 & 0.908 \\
\hline $\begin{array}{l}\text { I voluntarily answer questions (without being } \\
\text { called) in class }\end{array}$ & $\begin{array}{c}15 \\
(4.5 \%)\end{array}$ & $\begin{array}{c}32 \\
(9.6 \%)\end{array}$ & $\begin{array}{c}54 \\
(16.3 \%)\end{array}$ & $\begin{array}{c}190 \\
(57.2 \%)\end{array}$ & $\begin{array}{c}41 \\
(12.3 \%)\end{array}$ & 2.63 & 0.973 \\
\hline $\begin{array}{l}\text { In class, I choose a position which is most } \\
\text { visible to the teacher }\end{array}$ & $\begin{array}{c}12 \\
(3.6 \%)\end{array}$ & $\begin{array}{c}12 \\
(3.6 \%)\end{array}$ & $\begin{array}{c}35 \\
(10.5 \%)\end{array}$ & $\begin{array}{c}224 \\
(67.5 \%)\end{array}$ & $\begin{array}{c}49 \\
(14.8 \%)\end{array}$ & 2.86 & 0.840 \\
\hline$\overline{\text { Composite Scores }}$ & & & & & & 2.17 & 0.935 \\
\hline
\end{tabular}

Note: $\mathrm{N}=$ Never, $\mathrm{R}=$ Rarely, $\mathrm{S}=$ Sometimes, $\mathrm{U}=$ Usually, $\mathrm{A}=$ Always 
The composite score for the means was 2.17 and a composite score for the standard deviation was 0.935 . The composite mean score implied that there was a moderate level of academic self-esteem due to a values of 2.17 in a range of $0-4$. The mid-point for this range is 2.0 and therefore values in the grater than 1.5 but less than 2.5 indicates a moderate extent of the aspect being evaluated. The composite standard deviation implied that on average there was moderate consensus among the students in rating the various statements on student academic self-esteem. The statement that was highly and favourably rated is the statement that the students felt good about themselves when they attained good academic grades. The lowly and poorly rated aspect in student academic selfesteem was the aspect that students would rather spend most of their time reading as opposed to other activities. A study by Njenga (2018) noted that more needs to be done to improve the self-esteem of students in engaging learning activities. The study recommended students to be motivated towards changing their negative attitudes towards learning and embrace right attitudes towards academics. Parents were seen to have a significant role in changing the students' perceptions towards better academic achievements.

\section{Student Academic Achievement}

The study obtained the data on student academic achievement from examination records. Academic records for the previous three internal End of Term Examinations was considered in this study. Since different schools took different exams that are of different degree in complexity, the examinations mean scores were standardized using both the Z-Score and t-score in order to make the results comparable. The standardized results for the academic achievement were analyzed and the results presented in Table 2.

Table 2: Descriptive Statistics for Academic Achievement

\begin{tabular}{lc}
\hline Statistic & Value \\
\hline Minimum & 43.75 \\
Maximum & 76.25 \\
Mean & 60.0546 \\
Median & 59.3750 \\
Mode & 60.00 \\
Std. Deviation & 5.18680 \\
Variance & 26.903 \\
Skewness & 0.445 \\
Kurtosis & 0.274 \\
Valid N (listwise) & 332 \\
\hline
\end{tabular}

According to Table 14, the study revealed the lowest academic achievement mean score for the students who participated in this study was 43.75 marks while the highest academic achievement mean score was 76.25 marks out of a maximum score of 100 marks. This presents a range of 32.9 marks between the top student sampled in this study and the last bottom student sampled in this study. The mean average marks for the students sampled in this study was 60.0546 marks. This implied that on average students' academic achievement in public secondary schools in Nakuru County was moderately above the average mark of 50 marks. This is evidenced by a mode score of 60 marks. This implied that majority of the students score 60 marks (standardized scores) out of a possible score of 100 marks. The median academic mean score for the sample students was 59.3750. The median value was close to the mean score and the mode which then implied that the academic achievement of the students was normally distributed (Fallon, 2016). A variance of 26.903 and a standard deviation of 5.18680 was achieved in this study which therefore indicated that the academic achievement had a small deviation. This further shows that there is small disparity (Nayak, 2016) in terms of academic achievement of the sampled students in Nakuru County.

Skewness on the other hand was used to show the symmetry of data (Wooldridge, 2017). The obtained skewness was 0.445 . For a normally distributed data, the ideal skewness should be zero and therefore a skewness close to zero would imply that the data is normally distributed (Agresti, 2017). According to Clements and Sarama (2016), if the skewness is between -0.5 and 0.5 , the data is fairly symmetrical and therefore the achieved skewness in this study implied that the academic achievement of public secondary schools in Nakuru County was normally distributed (fairly symmetric). The achieved kurtosis for the academic achievement of students sampled in this 
study was 0.274 . Similarly, the kurtosis value for normally distributed data should be zero (Agresti, 2017) and therefore the academic achievement of students in public secondary schools in Nakuru County was normally distributed.

\section{Relationship between Students' Academic Self-Esteem and Academic Achievement}

The third hypothesis of the study stated that; $\mathbf{H}_{03}$ : There is no statistically significant relationship between students' academic self-esteem and achievement in public secondary schools in Nakuru County, Kenya. To test this hypothesis, correlation analysis was done as shown Table 3.

Table 3: Students' Academic Self-Esteem and Academic Achievement

\begin{tabular}{llc}
\hline Variable & & Esteem \\
\hline Academic & Pearson Correlation & $0.580^{* *}$ \\
Achievement & Sig. & 0.000 \\
& N & 332 \\
\hline
\end{tabular}

According to Table 3, it was established that there was statistically significant relationship between students' academic self-esteem and academic achievement in public secondary schools in Nakuru County due to a correlation coefficient of 0.580 and a p-value less than 0.05 . Therefore the third hypothesis of the study was rejected at $95 \%$ confidence interval and hence established that there was significant relationship between students' academic self-esteem and academic achievement in public secondary schools in Nakuru County, Kenya. It hence implied that if a student had a favourable self-esteem in academic affairs, the student is also likely to have a better academic achievement and the vice versa.

This is in line with Muhammad et al. (2015) who found out that there was a significant relationship between self-esteem and academic achievement of students. Muhammud (2015) also established that there was a significant $(\mathrm{p}<0.01)$ positive relationship between self-esteem and academic achievement. Maruyana et al. (2016) found out that there was significant difference between academic achievement of students with high self-esteem and students with low self-esteem. Mutua (2014) further established that there was significant relationship between self-esteem and academic achievement of the students. On Nigerian context, Akaase and Okpechi (2018) revealed that there was a significant difference in the academic success of students with positive self-esteem than those with negative self-esteem. It was concluded that self-esteem significantly influenced students' academic success. Contrary to the findings in the current study, Amirtha and Jebaseelan (2014) noted that there was no significant relationship between students' academic self-esteem and academic achievement.

\section{Conclusion}

The study concludes that there is a significant relationship exists between students' academic self-esteem and achievement in public secondary schools in Nakuru County, Kenya.

\section{Recommendations}

The study recommends the Kenya Institute of Curriculum Development (KICD) to develop a curriculum or teaching methods that seeks to improve student academic self-esteem in a learning environment like competency based curriculum (CBC). The study also recommends the Ministry of Education to formulate policies by prioritizing as much as possible aspects of student academic self-esteem aimed at improving the academic achievement of students in secondary schools. It is further recommended that teachers to motivate students to adjust their academic self-esteem for better academic achievement in terms of viewing learning activities in the school as fun, feeling good when in a class learning, enjoy spending many hours on academic homework and spend most of their time reading as opposed to other activities. This is likely to improve the academic achievement of students. For future research, an investigation can be done to compare students' academic self-esteem in boarding and Day secondary schools and establish whether the differences if any affect the academic achievement of the students. A comparative study can also be conducted in other counties in Kenya to establish whether students' academic self-esteem affects the level of academic achievement of students in both public and private secondary schools. 


\section{References}

Agresti, A. (2017). An Introduction to Categorical Data Analysis: Second Edition. Florida: John Wiley \& Sons Publication.

Akaase, B., \& Okpechi, P. (2018). Self-Esteem and Academic Success of Secondary School Students in Calabar Metropolis of Cross River State , Nigeria and Counseling Interventions. Research Journal of Education, 4(2018), 175-179.

Alyami, M., Melyani, Z., Johani, A. Al, \& Ullah, E. (2017). The Impact of Self-Esteem , Academic Self-Efficacy and Perceived Stress on Academic Performance : A Cross-Sectional Study of Saudi Psychology Students. European Journal of Educational Sciences, 4(3), 51-63.

Amirtha, M., \& Jebaseelan, U. S. (2014). Student Learning Behavior And Academic Achievement: Unraveling Its Relationship. Indian Journal of Applied Research, 4(12), 7-9.

Anderman, E. M., \& Midgley, C. (1997). Changes in Achievement Goal Orientations, Perceived Academic Competence and Grades across the Transition to Middle-Level Schools. Contemporary Educational Psychology, 22(3), 269-298.

Bahar, M. (2016). Student Perception of Academic Achievement Factors at High School. European Journal of Educational Research, 5(2), 85-100.

Bean, R., Bush, R., McKenry, C., \& Wilson, M. (2013). The Impact of Parental Support, Behavioral Control, and Psychological Control on the Academic Achievement and Self-Esteem of African-American and European American Adolescents. Journal of Adolescent Research, 18(3), 523-541.

Browne, M. W., \& Cudeck, R. (1993). Testing Structural Equation. Newbury Park: Stage Publications.

Clements, D. H., \& Sarama, J. (2016). Handbook of Research Methods in Early Childhood Education: Methods for Developing Scientific Education. London: Infonnalion Age Publishing.

Cuesta, A. (2018). Child Work and Academic Achievement: Evidence from Young Lives in Ethiopia. Andhra Pradesh: University of Minnesota.

Durmaz, G. B. (2016). The Self-Care Training is Increasing Body Image Perception Self- Esteem and Self-Care Abilities in Pregnant Adolescents : A Pretest- Posttest Quasi-Experimental Study. International Journal of Caring Sciences, 9(3), 876-882.

Einstein, A., Addams, J., \& Roosevelt, E. (2016). Maslow's hierarchy of needs, 1-6.

Elliot, A. (2006). The Hierarchical Model of Approach-Avoidance Motivation. Motivation and Emotion, 30(2), $111-116$.

Fallon, M. (2016). Writing up Quantitative Research in the Social and Behavioral Sciences. Rotterdam: Sense Publishers.

Farhan, P. S. (2015). Impact of Stress, Self-Esteem and Gender Factor on Students' Academic Achievement. International Journal on New Trends in Education and Their Implications, 6(2), 143-156.

Gupta, P. K., \& Mili, R. (2016). Impact of Academic Motivation on Academic Achievement: A Study on High Schools Students. European Journal of Education Studies, 43-51.

Hasebur Rahman, M., \& M. Nurullah, S. (2015). Motivational Need Hierarchy of Employees in Public and Private Commercial Banks. Central European Business Review, 3(2), 44-53. https://doi.org/10.18267/j.cebr.84

Kaplan, A., \& Maehr, M. L. (2007). The Contributions and Prospects of Goal Orientation Theory. Educational Psychology Review, 6(5), 7-12.

Kithela, S. M. (2016). Relationship among School Type and Secondary School Students' Self-Esteem, Academic Achievement and Career Aspirations in Nairobi County, Kenya. International Journal of Education and Research, 7(4), 34-39.

Luo, W., Hogan, D., Tan, L. S., Kaur, B., Ng, P. T., \& Chan, M. (2014). Self-Construal and Students' Math SelfConcept, Anxiety and Achievement: An Examination of Achievement Goals as Mediators. Asian Journal of Social Psychology, 1(7), 184-195.

Maruyana, G., Rubin, G. G., \& Kingsbury, G. K. (2016). Influence of Self-Esteem on Academic Performance among Secondary School Students. Journal of Personality and Social Psychology, 40(2), 6-9.

Masselink, M., Roekel, E., \& Oldehinkel, A. (2018). Self-esteem in Early Adolescence as Predictor of Depressive Symptoms in Late Adolescence and Early Adulthood: The Mediating Role of Motivational and Social Factors. Journal of Youth and Adolescence, 47(5), 932-946. https://doi.org/10.1007/s10964-017-0727-z 
McGaha-Garnett, V. (2017). The Effects of Violence on Academic Progress and Classroom Behavior: From a Pa rent's Perspective. IOSR Journal Of Humanities And Social Science, 3(2), 98-102.

Muhammad, A., Muhammad, Z., \& Mahmood, K. (2015). Relationship between Self-Esteem and Academic Achievement of Secondary School Students. Journal of Education and Practice, 4(3), 13-21.

Muhammud. (2015). Relationship between Self-Esteem and Academic Achievement among Pre-University Students. Indian Journal of Applied Research, 7(3), 1-12.

Murunga, O. L., \& Obuba, E. (2017). Investigation of the Influence of Class Size on Internal Efficiency of Public Secondary Schools in Teso North Sub County . International Journal of Humanities and Social Science Invention, 6(11), 37-42.

Mutua, M. S. (2014). Academic Motivation and Self-Regulated Learning as Predictors of Academic Achievement of Students in Public Secondary Schools in Nairobi County, Kenya. Contemporary Educational Psychology, 5(5), 11-26.

Nakuru County Director of Education. (2018). Kenya Certificate of Secondary Education Records. Nakuru: Kenya.

Nayak, J. K. (2016). Fundamentals of Research Methodology: Problems and Prospects. New Delhi: SSDN Publishers \& Distributors.

Njenga, J. (2018). Evaluation of The Effectiveness of Cooperative Learning Structures in Improving Students' Performance. Journal of Engineering Education, 1(1), 12-24.

Ntawiha, P. (2016). Educational Inputs and their Implications for Output in Public Secondary Schools in Nyarugenge and Nyamasheke Districts, Rwanda. Unpublished Doctor of Arts Thesis: Keele University.

Okolo, V., Ofielu, M., Nebo, G., \& Nebo, G. (2017). Assessing Factors Influencing Academic Performance of Undergraduate Students in Nigerian University: A Study of University of Port Harcourt. International Journal of Research in Economics and Social Sciences (IJRESS), 7(9), 223-250.

Orth, U., Robins, R. W., \& W, R. (2014). The Development of Self-Esteem. Current Directions in Psychological Science, 23(5), 381-387.

Perva, D. (2016). Impact Of School Facilities On Students' Academic Performances In Public Secondary Schools In Giwa And Zaria Education Zones, Kaduna State, Nigeria. Journal of Education and Policy Making, 4(9), $16-29$.

Phil, R. A. M., Sattar, A., Khan, I., \& Phil, F. J. M. (2014). The Mental grooming and Self-esteem of the Students through Co-curricular activities : A Teacher's view. Research on Humanities and Social Sciences, 4(19), $138-142$.

Pitan, O., \& Susan, O. (2012). Analysis of Internal Efficiency in the Utilization of Human Resources in Selected Secondary Schools of Oyo State, Nigeria. Journal of Emerging Trends in Educational Research and Policy Studies (JETERAPS), 3(5), 748-752.

Riswanto, A., \& Aryani, S. (2017). Learning Motivation and Student Achievement: Description Analysis and Relationships. The International Journal of Counseling and Education, 2(1), 42-57.

Sahin, E., Barut, Y., Ersanli, E., \& Kumcagiz, H. (2014). Self-Esteem and Social Appearance Anxiety: An Investigation of Secondary School Students. J. Basic. Appl. Sci. Res, 4(3), 152-159.

Serati, F. (2015). The Relationship between Self-Esteem of Mothers and Depression among Male Secondary School Students in District 2 in Zanjan, Iran. International Journal of Academic Research in Business and Social Sciences, 5(3), 143-148.

Sharma, S., \& Agarwala, S. (2015). Self-Esteem and Collective Self-Esteem Among Adolescents: An Interventional Approach. Psychological Thought, 8(1), 105-113. https://doi.org/10.5964/psyct.v8i1.121

Srivastava, R., \& Joshi, S. (2014). Relationship between Self-concept and Self-esteem in Adolescents. International Journal of Advanced Research, 2(2), 36-43.

Suleman, Q., \& Gul, R. (2015). Challenges to Successful Total Quality Management Implementation in Public Secondary Schools : A Case Study of Kohat District, Pakistan. Journal of Education and Practice, 6(15), 123-135.

Urdan, T., \& Midgley, C. (2003). Changes in the Perceived Classroom Goal Structure and Pattern of Adaptive Learning during Early Adolescence. Contemporary Educational Psychology, 2(8), 524-551.

Vass, V., Morrison, A. P., Law, H., Dudley, J., Taylor, P., Bennett, K. M., \& Bentall, R. P. (2015). How stigma 
impacts on people with psychosis: The mediating effect of self-esteem and hopelessness on subjective recovery and psychotic experiences. Psychiatry Research, 230(2), 487-495. https://doi.org/10.1016/j.psychres.2015.09.042

Wooldridge, J. M. (2017). Econometric Analysis of Cross Section and Panel Data. London: MIT Press. 